Psychology of Language and Communication 2014, Vol. 18, No. 3

DE GRUYTER

OPEN

DOI: $10.2478 /$ plc-2014-0017

JAN E. OKUNIEWSKI

University of Warsaw

\title{
AGE AND GENDER EFFECTS ON MOTIVATION AND ATTITUDES IN GERMAN LEARNING: THE POLISH CONTEXT
}

\begin{abstract}
The research investigates the German language learning motivations of Polish secondary school students and university students. Questionnaire data were collected from $247 \mathrm{stu}-$ dents (126 from secondary school and 121 from university). The aim of this research was to examine the relationships among language attitudes, instrumental, cultural interest, integrative, L2 self and motivated learning. The results show the existence of age and gender difference in variables under consideration. Relationships were found between age and gender to the motivational attitudes: older and female students had a more integrative attitude than younger and mail students and experienced more intensive motivation. Key words: language learning, age, gender, second language motivation, language attitudes, German language
\end{abstract}

The analysis presented here aims to investigate the effect of age and gender on motivation to learn German as a second language. The paper is based on the assumptions of Gardner's model, known as the Socio-Educational Model (2010), and Dörnyei's model, known as the Motivational Self System (2005).

\section{Review of literature}

A theory related to second language learning motivation was outlined by Robert C. Gardner in his Socio-Educational Model (Gardner, 1985). Gardner's model is hierarchical and promotes the idea of integrative motivation. It is based

Address for correspondence: Jan E. Okuniewski, "Psychology of Language and Communication”, Faculty of Psychology, University of Warsaw, Stawki 5/7, 00-183 Warsaw, Poland. E-mail: plc@psych.uw.edu.pl 
on the assumption that learning a foreign language is different in many respects from learning other subjects because language helps build the social essence of human beings and is an important part of their identity (Gardner, 2001). Gardner's model concerns not only the desire to learn the language itself, but also to learn about the community linked to it and that community's culture, a desire to meet people and make contact with them, readiness to join in the functioning of a given language community. It also accounts for other factors that affect motivation, such as the attitude toward communities that use a given language, and even a general interest in foreign languages.

Gardner's research also encompassed the following aspects of motivation: instrumental orientation, attitude toward learning situation, parental encouragement and language anxiety (Gardner, 2007, 2010). Besides motivation, the model also considers learning factors that can have a direct impact on language acquisition achievements.

A model that tries to account for different factors affecting motivation in second language learning is the concept of Motivational Self System in Dörnyei's approach (Dörnyei, 2005, 2009). The Motivational Self System contains three important aspects: Ideal L2 Self (seeing oneself as an effective user of the second language), Ought-to Self (believing that one ought to be able to use a second language) and L2 Learning Experience (an aspect related to the learning environment).

Numerous studies on second language acquisition have analyzed different factors and mechanisms linked to age in L2 learning. One example of such research is a comparison of Hungarian secondary school students, university students and adults in terms of their motivation to learn a second language (Kormos and Csizér, 2008). Similar studies on motivation in foreign language learning were conducted by $\mathrm{Xu}$ and Case (in press) in three age groups: Chinese elementary, middle, and high school students.

Many studies on differences in motivation to learn foreign languages have shown stronger motivation among female than male learners. A slightly higher level of motivation among girls than boys has been established by research in different countries, including Canada (Kissau, 2006; Kissau et al., 2010), China (Ahåt, 2013), the United Kingdom (Williams et al., 2002), Hungary (Dörnyei et al., 2006), Korea (Kim \& Kim, 2011), Poland (Okuniewska et al., 2010), Sweden (Henry, 2009), Turkey (Öztürk \& Gürbüz, 2013; Polat, 2011) and the United States (Brantmeier et al., 2013; Chavez, 2014). Males were less motivated than females when learning various languages, for example English (Dörnyei et al., 2006; Henry, 2009; Kim \& Kim, 2011; Ahåt, 2013; Öztürk \& Gürbüz, 2013), French (Williams et al., 2002, Kissau, 2006; Dörnyei et al., 2006), German (Williams et al., 2002, Dörnyei et al., 2006; Chavez, 2014), Hebrew (Okuniewska et al., 2010), Italian (Dörnyei et al., 2006), Kurdish (Polat, 2011), Russian (Dörnyei et al., 2006) and Spanish (Kissau et al., 2010; Brantmeier et al., 2013). 
Table 1. Demographic data

\begin{tabular}{lccccc}
\hline & $\begin{array}{c}\text { Public school } \\
\text { students in } \\
\text { Warsaw }\end{array}$ & $\begin{array}{c}\text { Private school } \\
\text { students in } \\
\text { Warsaw }\end{array}$ & $\begin{array}{c}\text { University } \\
\text { of Warsaw } \\
\text { students }\end{array}$ & $\begin{array}{c}\text { Warsaw } \\
\text { School of } \\
\text { Economics } \\
\text { students }\end{array}$ & Total \\
\hline $\mathrm{N} \quad 108$ & 18 & 62 & 59 & 247 \\
Mean age & $16 ; 7$ & $17 ; 0$ & $21 ; 1$ & $20 ; 7$ & $18 ; 8$ \\
Gender Male (N) & 65 & 7 & 24 & 32 & 128 \\
Female (N) & 43 & 11 & 38 & 27 & 119 \\
$\begin{array}{l}\text { Mean time of } \\
\text { learning German }\end{array}$ & 7.52 & 9.00 & 15.39 & 16.76 & 11.81 \\
(number of semesters) & & & & & \\
\hline
\end{tabular}

\section{Problem}

In the study presented below we consider the effect of age and gender on the motivation of Polish speakers learning German as an additional second language (English was the mandatory L2).

\section{Method}

\section{Participants}

In total, 247 students of German participated in the study (119 females and 128 males). The study was conducted in Warsaw at general secondary schools (public and private) and also at universities (University of Warsaw and Warsaw School of Economics). The study included 126 school students (54 female and 72 male) from two general secondary schools, ranging in age from 15 to 18 years, and 121 university students (65 female and 56 male) ranging in age from 19 to 25 years. They all took German as an additional second language (besides the obligatory English). The participants from general secondary schools started to learn German between the age of 7 and 15, and from universities between the age of 6 and 18. Table 1 summarizes the participants' characteristics.

\section{Materials and procedure}

Data were collected with the help of a questionnaire adapted (partially) from (1) the Attitude/Motivation Test Battery (Gardner, 2004) and (2) the Language Disposition Questionnaire (Dörnyei et al., 2006). The questionnaire used in this study contained 54 items for secondary school and university students. The expanded scope of the study on factors in second language learning motivation also includes two new variables: ideal L2 self and ought-to L2 self. For items, students 
had to indicate on a 6-point scale to what extent they agreed or disagreed with statements. The statements were intended to cover the following variables:

Attitudes to the international status of German (4 statements) - the extent to which students are willing to learn German as a foreign language. Example: "German is taught to many people around the world."

Milieu - the attitude of people in the students' immediate environment (4 statements) - the attitude of persons in the students' immediate environment concerning the importance of learning German. Example: "Many of my close friends also learn German."

German use anxiety (4 statements) - the level of anxiety felt by students when they use German in everyday life. Example: "I still have the impression that the other students speak German better than I do."

Instrumental orientation (4 statements) - interest in learning German in order to achieve utilitarian benefits such as better jobs or higher social status. Example: "Learning German is important to me because it will be useful in getting a good job."

Attitudes to German language communities (4 statements) - statements concerning the Austrian, German and Swiss communities' role in today's world. Example: "I would like to know more native German speakers."

Parental encouragement (4 statements) - the extent to which parents encourage their children to learn German. Example: "My parents encourage me to practice my German as much as possible."

Cultural interest - attitudes to German cultural products (4 statements) - attitudes to German culture, cultural products and events. Example: "German-speaking countries have a rich cultural heritage."

Integrative orientation (4 statements) - interest in learning German in order to interact, meet and socialize with members of German language communities. Example: "Learning German is important to me because it will enable me to better understand and appreciate the German way of life."

Interest in foreign languages (4 statements) - the extent to which students are interested in using foreign languages. Example: "I would like to be able to speak various foreign languages fluently."

Ideal L2 self (6 statements) - beliefs of students regarding the successful use of a second language. Example: "I can imagine that I am talking in German like a native speaker."

Ought-to L2 self(6 statements) - students' perceptions of how important learning German is in the opinion of significant others. Example: "I learn German because my close friends think it is very important."

Motivational intensity (6 statements) - persistence in language study, intended learning effort, enjoyment derived from learning German. Example: "If German was not taught in my school, I would try to take German lessons somewhere else." 
Table 2. Reliability coefficients for the questionnaire scales, means and standard deviations

\begin{tabular}{|c|c|c|c|c|}
\hline \multirow[t]{2}{*}{ Scales } & \multicolumn{2}{|c|}{$\begin{array}{l}\text { Secondary school } \\
\text { students }\end{array}$} & \multicolumn{2}{|c|}{$\begin{array}{l}\text { University } \\
\text { students }\end{array}$} \\
\hline & Cronbach's $\alpha$ & Mean / SD & Cronbach's $\alpha$ & Mean / SD \\
\hline $\begin{array}{l}\text { Attitudes to the } \\
\text { international status } \\
\text { of German }\end{array}$ & 0.89 & $3.89 / 0.91$ & 0.82 & $4.37 / 0.83$ \\
\hline $\begin{array}{l}\text { Milieu - the attitude of } \\
\text { people in the students' } \\
\text { immediate environment }\end{array}$ & 0.89 & $3.03 / 0.84$ & 0.81 & $3.40 / 0.87$ \\
\hline German use anxiety & 0.94 & $3.16 / 1.10$ & 0.89 & $3.16 / 0.98$ \\
\hline Instrumental orientation & 0.89 & $3.88 / 1.16$ & 0.82 & $4.85 / 0.72$ \\
\hline $\begin{array}{l}\text { Attitudes to German } \\
\text { language communities }\end{array}$ & 0.89 & $3.59 / 1.09$ & 0.82 & $4.57 / 0.79$ \\
\hline Parental encouragement & 0.90 & $3.06 / 1.09$ & 0.84 & $3.47 / 1.08$ \\
\hline $\begin{array}{l}\text { Cultural interest- } \\
\text { attitudes to German } \\
\text { cultural products }\end{array}$ & 0.90 & $2.98 / 0.83$ & 0.82 & $3.99 / 0.84$ \\
\hline Integrative orientation & 0.89 & $3.38 / 1.22$ & 0.80 & $4.27 / 1.00$ \\
\hline Interest in foreign languages & 0.90 & $4.69 / 0.83$ & 0.82 & $5.30 / 0.61$ \\
\hline Ideal L2 self & 0.89 & $3.10 / 1.19$ & 0.82 & $4.29 / 1.03$ \\
\hline Ought-to L2 self & 0.90 & $2.64 / 0.93$ & 0.82 & $3.11 / 0.91$ \\
\hline Motivational intensity & 0.89 & $3.09 / 1.08$ & 0.81 & $3.94 / 0.94$ \\
\hline
\end{tabular}

An official letter about the research questionnaire was submitted to the managements of the secondary schools and university language learning centers. The questionnaire was conducted personally in the presence and under the control of German teachers. Students participated in the study voluntarily. The questionnaires were completed during class time and the respondents were given as much time as they needed to fill in the data.

Table 2 presents the Cronbach's Alpha reliability coefficients of the scales based on the data collected from the study.

\section{Results}

The relationship between attitudes in the two age and gender groups was analyzed by using one-way ANOVA with repeated measurements. The results of the within-group comparison show considerable attitude differences between 
Table 3. Descriptive statistics concerning the results of the two age groups

\begin{tabular}{|c|c|c|c|c|}
\hline Scales & Age of students & $\mathrm{N}$ & Mean / SD & $\mathrm{F}$ \\
\hline $\begin{array}{l}\text { Attitudes to the } \\
\text { international status } \\
\text { of German }\end{array}$ & $\begin{array}{l}\text { Secondary school } \\
\text { University }\end{array}$ & $\begin{array}{l}126 \\
121\end{array}$ & $\begin{array}{l}3.89 / 0.91 \\
4.37 / 0.83\end{array}$ & $17.961^{* * *}$ \\
\hline $\begin{array}{l}\text { Milieu - the attitude of } \\
\text { people in the students' } \\
\text { immediate environment }\end{array}$ & $\begin{array}{l}\text { Secondary school } \\
\text { University }\end{array}$ & $\begin{array}{l}126 \\
121\end{array}$ & $\begin{array}{l}3.03 / 0.84 \\
3.40 / 0.87\end{array}$ & $11.635^{* *}$ \\
\hline German use anxiety & $\begin{array}{l}\text { Secondary school } \\
\text { University }\end{array}$ & $\begin{array}{l}126 \\
121\end{array}$ & $\begin{array}{l}3.16 / 1.10 \\
3.16 / 0.98\end{array}$ & 0.003 \\
\hline Instrumental orientation & $\begin{array}{l}\text { Secondary school } \\
\text { University }\end{array}$ & $\begin{array}{l}126 \\
121\end{array}$ & $\begin{array}{l}3.88 / 1.16 \\
4.85 / 0.72\end{array}$ & $62.002^{* * *}$ \\
\hline $\begin{array}{l}\text { Attitudes to German } \\
\text { language communities }\end{array}$ & $\begin{array}{l}\text { Secondary school } \\
\text { University }\end{array}$ & $\begin{array}{l}126 \\
121\end{array}$ & $\begin{array}{l}3.59 / 1.09 \\
4.57 / 0.79\end{array}$ & $64.905^{* * *}$ \\
\hline Parental encouragement & $\begin{array}{l}\text { Secondary school } \\
\text { University }\end{array}$ & $\begin{array}{l}126 \\
121\end{array}$ & $\begin{array}{l}3.06 / 1.09 \\
3.47 / 1.08\end{array}$ & $8.986^{* *}$ \\
\hline $\begin{array}{l}\text { Cultural interest - } \\
\text { attitudes to German } \\
\text { cultural products }\end{array}$ & $\begin{array}{l}\text { Secondary school } \\
\text { University }\end{array}$ & $\begin{array}{l}126 \\
121\end{array}$ & $\begin{array}{l}2.98 / 0.83 \\
3.99 / 0.84\end{array}$ & $91.252^{* * *}$ \\
\hline Integrative orientation & $\begin{array}{l}\text { Secondary school } \\
\text { University }\end{array}$ & $\begin{array}{l}126 \\
121\end{array}$ & $\begin{array}{l}3.38 / 1.22 \\
4.27 / 1.00\end{array}$ & $38.988^{* * *}$ \\
\hline Interest in foreign languages & $\begin{array}{l}\text { Secondary school } \\
\text { University }\end{array}$ & $\begin{array}{l}126 \\
121\end{array}$ & $\begin{array}{l}4.69 / 0.83 \\
5.30 / 0.61\end{array}$ & $43.065^{* * *}$ \\
\hline Ideal L2 self & $\begin{array}{l}\text { Secondary school } \\
\text { University }\end{array}$ & $\begin{array}{l}126 \\
121\end{array}$ & $\begin{array}{l}3.10 / 1.19 \\
4.29 / 1.03\end{array}$ & $69.820^{* * *}$ \\
\hline Ought-to L2 self & $\begin{array}{l}\text { Secondary school } \\
\text { University }\end{array}$ & $\begin{array}{l}126 \\
121\end{array}$ & $\begin{array}{l}2.64 / 0.93 \\
3.11 / 0.91\end{array}$ & $16.477^{* * *}$ \\
\hline Motivational intensity & $\begin{array}{l}\text { Secondary school } \\
\text { University }\end{array}$ & $\begin{array}{l}126 \\
121\end{array}$ & $\begin{array}{l}3.09 / 1.08 \\
3.94 / 0.94\end{array}$ & $43.355^{* * *}$ \\
\hline
\end{tabular}

Note: ${ }^{*} p<0.05 ;{ }^{* *} p<0.01 ;{ }^{* * *} p<0.001$

age groups and also gender groups. Significant results have been established in terms of the overall study variable.

A comparison of the data from remarks on the five main components with reference to age groups contains the results between younger students from secondary school and slightly older students from university. These results, as well as their significance levels, are provided in Table 3. A distinct advantage was found in most slightly older university students over younger secondary 
school students in almost all five main components: motivation (motivational intensity), attitudes toward the learning situation (attitudes to the international status of German, attitudes to German language communities, interest in foreign languages), orientation in language learning (integrative orientation, instrumental orientation), certain social relations of interest in foreign language learning (parental encouragement, milieu - the attitude of people in the students' immediate environment, cultural interest - attitudes to German cultural products) and specific aspects of the second language (ideal L2 self, ought-to L2 self). The only factor which did not yield higher results in either of the two groups is the question concerning anxieties, uncertainty and a certain fear (German use anxiety) when using the foreign language during learning.

The next results, pertaining to the impact of gender, were considered in two sections: the two gender groups among secondary school students and the two gender groups among university students. Data from these two analyses are presented in Table 4.

Interestingly, differences in the range analysis of the secondary school student gender groups are almost identical as the results concerning age groups. With respect to almost all the orientations, males reported significantly lower scores than females: motivation (motivational intensity), attitudes toward the learning situation (attitude to the international status of German, attitude to German language communities, interest in foreign languages), orientation in language learning (integrative orientation, instrumental orientation), certain social relations of interest in foreign language learning (parental encouragement, milieu - the attitude of people in the students' immediate environment, cultural interest - attitudes to German cultural products) and specific aspects of the second language (ideal L2 self, ought-to L2 self). Similarly to the age-group analysis, in the question on anxieties, uncertainty and fear (German use anxiety) neither of the gender groups had a significantly different result.

A second finding shows some significant differences between the university student gender groups. In this analysis, some of the results of females are still higher than males, but the two gender groups have several equally positive attitudes regarding some of the factors. The following variables yielded higher scores among females than males: motivation (motivational intensity), attitudes toward the learning situation (attitude to the international status of German, attitude to German language communities, interest in foreign languages), orientation in language learning (integrative orientation), certain social relations of interest in foreign language learning (milieu - the attitude of people in the students' immediate environment) and specific aspects of the second language (ideal L2 self, ought-to L2 self). Slight and irrelevant differences in the decisions of men and women were found for the following four variables: anxieties, uncertainty and fear (German use anxiety), interest in learning German (instrumental orientation), encouraged learning of foreign languages (parental encouragement) and 


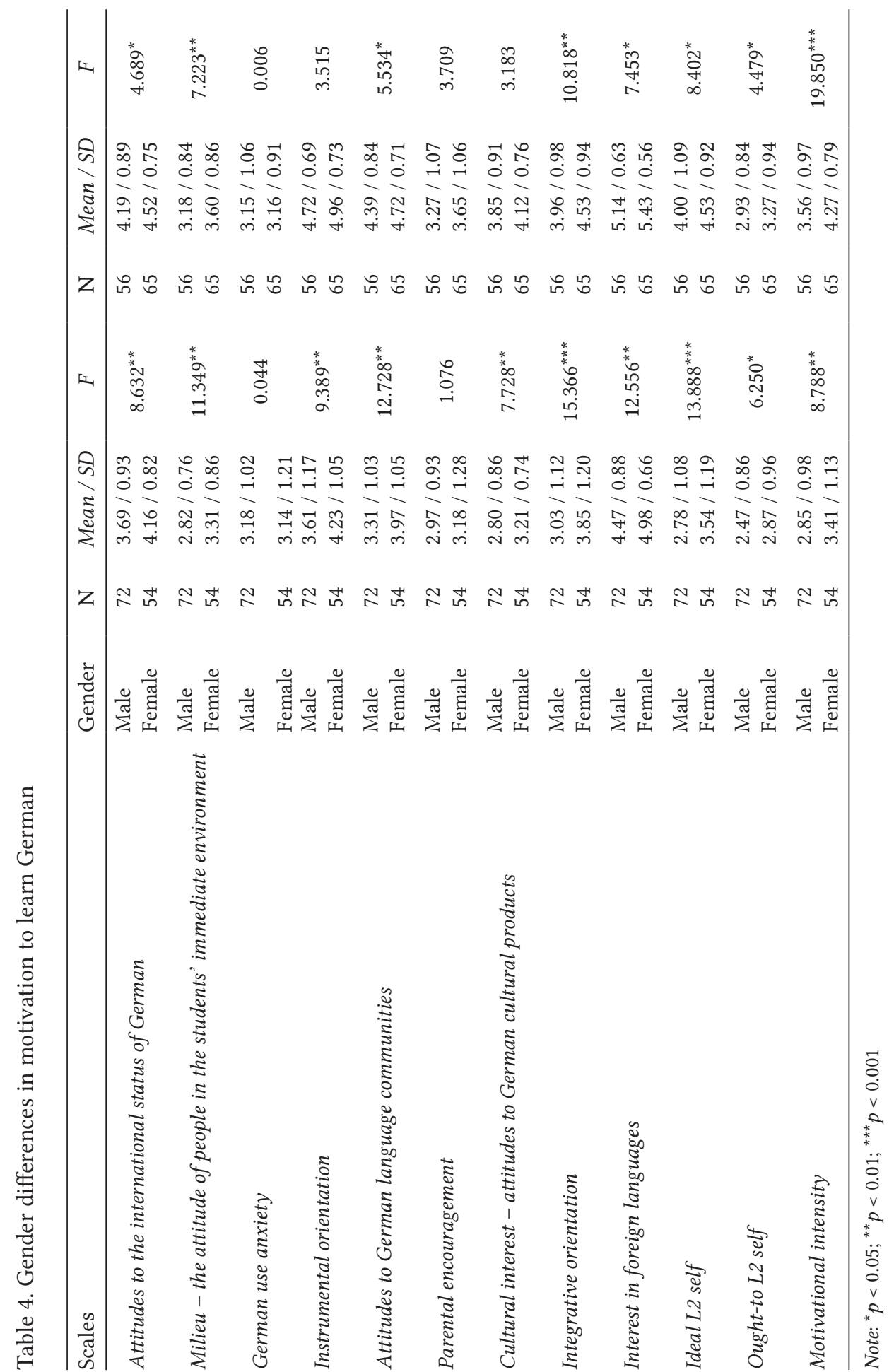


attitudes to cultural products and events (cultural interest - attitude to German cultural products).

Another analysis considered the data by type of school. The first comparison was between public school and private Catholic school students. Nonparametric statistics (Mann-Whitney $U$ test) was used for this analysis that compared interest in learning German in these two types of schools. The two groups were not statistically different on attitudes toward the foreign language:

- attitudes to the international status of German (public school students Mean $=3.94, S D=0.86$, private school students - Mean $=3.63, S D=1.14$; $U=811.50, p=0.261$;

- milieu - the attitude of people in the students' immediate environment (public school students - Mean $=3.01, S D=0.75$, private school students - Mean $=3.18, S D=1.27 ; U=944.50, p=0.847)$;

- German use anxiety (public school students - Mean $=3.21, S D=1.07$, private school students - Mean $=2.86, S D=1.26 ; U=749.00, p=0.119$ );

- instrumental orientation (public school students - Mean $=3.94, S D=1.03$, private school students - Mean $=3.49, S D=1.73 ; U=878.50, p=0.513$ );

- attitudes to German language communities (public school students Mean $=3.63, S D=1.04$, private school students - Mean $=3.35, S D=1.35$; $U=851.50, p=0.399$ );

- parental encouragement (public school students - Mean $=3.07, S D=0.93$, private school students - Mean $=3.00, S D=1.82 ; U=822.00, \mathrm{p}=0.294)$;

- cultural interest - attitudes to German cultural products (public school students - Mean $=3.00, S D=0.82$, private school students - Mean $=2.86$, $S D=0.91 ; U=859.00, p=0.428)$

- integrative orientation (public school students - Mean $=3.39, S D=1.15$, private school students - Mean $=3.35, S D=1.64 ; U=943.00, p=0.839$ );

- interest in foreign languages (public school students - Mean $=4.72$, $S D=0.75$, private school students - Mean $=4.49, S D=1.18 ; U=920.50$, $p=0.718$;

- ideal L2 self (public school students - Mean $=3.12, S D=1.09$, private school students - Mean $=3.03, S D=1.70 ; U=882.00, p=0.530$ );

- ought-to L2 self (public school students - Mean $=2.65, S D=0.89$, private school students - Mean $=2.56, S D=1.13 ; U=894.50, p=0.588$;

- motivational intensity (public school students - Mean $=3.07, S D=0.96$, private school students - Mean $=3.22, S D=1.64 ; U=928.00, p=0.759)$.

Another analysis demonstrated some differences between the two university groups. The University of Warsaw (UW) group comprised students of the humanities while the Warsaw School of Economics (SGH) group comprised students of economic and technical sciences. The subject of studies affected the results for different factors. The results of SGH students were higher for interest in learning German (instrumental orientation: UW students - Mean $=4.68$, 
$S D=0.70$, SGH students - Mean $=5.03, S D=0.70 ; F=7,688, p<0.01)$ and perceptions of how important learning a foreign language is (ought-to L2 self: $\mathrm{UW}$ students - Mean $=2.85, S D=0.82$, SGH students - Mean $=3.40, S D=0.92$; $F=12,026, p<0.001)$. UW students had higher outcomes for attitudes to cultural products and events (cultural interest - attitudes to German cultural products: UW students - Mean $=4.15, S D=0.87$, SGH students - Mean $=3.83, S D=0.79$; $F=4,233, p<0.05)$. The other results of the two groups were not statistically different:

- attitudes to the international status of German (UW students - Mean $=4.36$, $S D=0.84$, SGH students - Mean $=4.37, S D=0.83 ; F=0.009, p=0.927)$;

- milieu - the attitude of people in the students' immediate environment $(\mathrm{UW}$ students - Mean $=3.34, \mathrm{SD}=0.88, \mathrm{SGH}$ students - Mean $=3.47$, $S D=0.87 ; F=0.600, p=0.440)$;

- German use anxiety (UW students - Mean $=3.19, S D=1.00$, SGH students - Mean $=3.12, S D=0.96 ; F=0.123, p=0.726$;

- attitudes to German language communities (UW students - Mean $=4.50$, $S D=0.84$, SGH students - Mean $=4.64, S D=0.73 ; F=1,013, p=0.316$ );

- parental encouragement (UW students - Mean $=3.53, S D=1.12, \mathrm{SGH}$ students - Mean $=3.42, S D=1.04 ; F=0.331, p=0.566$ );

- integrative orientation (UW students - Mean $=4.31, S D=1.05$, SGH students - Mean $=4.23, S D=0.94 ; F=0.182, p=0.670)$;

- interest in foreign languages (UW students - Mean $=5.26, S D=0.59$, SGH students - Mean $=5.33, S D=0.63 ; F=0.425, p=0.515)$;

- ideal L2 self (UW students - Mean $=4.15, S D=1.13$, SGH students Mean $=4.44, S D=0.89 ; F=2,427, p=0.122)$;

- motivational intensity (UW students - Mean $=3.81, S D=1.03$, SGH students - Mean $=4.09, S D=0.82 ; F=2,748, p=0.100$ ).

\section{Conclusions}

The study presented here shows the psychological applicability of the models of Gardner and Dörnyei in research on motivation to learn German as a (nonmandatory) second language among secondary school and university students whose L1 is Polish. Five main components were analyzed: motivation (motivational intensity, German use anxiety), attitudes toward the learning situation (attitudes to the international status of German, attitudes to German language communities, interest in foreign languages), orientation in language learning (integrative orientation, instrumental orientation), certain social relations of interest in foreign language learning (parental encouragement, milieu - the attitude of people in the students' immediate environment, cultural interest - attitudes to German cultural products) and specific aspects of the second language (ideal L2 self, ought-to L2 self). In total 12 specific factors were analyzed as those influ- 
encing second language motivation. Age and gender differences were found in the motivation to learn German as an additional L2. Older and female students had a more integrative attitude than younger and male students and experienced more intensive motivation.

\section{References}

Ahåt, R. (2013). Motivation, gender, and learner performance of English as an L3 in the Xinjiang Uyghur Autonomous Region. English Language Teaching, $6(9), 158-167$.

Brantmeier, C., Callender, A, \& McDaniel M. (2013). The role of gender, embedded questions, and domain specific readings with learners of Spanish. Hispania, 96 (3), $562-578$

Chavez, M. (2014). Variable beliefs about the need for accuracy in the oral production of German: An exploratory study. International fournal of Applied Linguistics, 24 (1), 97-127.

Dörnyei, Z. (2005). The Psychology of the Language Learner Individual Differences in Second Language Acquisition. Mahwah, NJ: Lawrence Erlbaum Associates.

Dörnyei, Z. (2009). The L2 Motivational Self System. In Z. Dörnyei \& E. Ushioda (Eds.), Motivation, Language Identity and the L2 Self (pp. 9-42). Bristol: Multilingual Matters.

Dörnyei, Z., Csizér, K., \& Németh, N. (2006). Motivation, Language Attitudes and Globalisation: A Hungarian Perspective. Clevedon: Multilingual Matters.

Gardner, R.C. (1985). Social Psychology and Second-Language Learning: The Role of Attitudes and Motivation. London: Arnold.

Gardner, R.C. (2001). Integrative motivation and second language acquisition. In Z. Dörnyei \& R. Schmidt (Eds.), Motivation and second language acquisition (pp. 1-20). Honolulu, HI: University of Hawaii Press.

Gardner, R.C. (2004). Attitude/Motivation Test Battery: International AMTB Research Project. Retrieved 5.06.2010 from:

http://publish.uwo.ca/ gardner/docs/englishamtb.pdf

Gardner, R.C. (2006). The socio-educational model of second language acquisition: A research paradigm. In S.H. Foster-Cohen, M. Medved Krajnović, \& J. Mihaljević Djigunović (Eds.), EUROSLA Yearbook. Volume 6 (pp. 237-260). Amsterdam: John Benjamins.

Gardner, R.C. (2007). Motivation and second language acquisition. Porta Linguarum, 8, 9-20.

Gardner, R.C. (2010). Motivation and Second Language Acquisition. The SocioEducational Model. New York: Peter Lang.

Henry, A. (2009). Gender differences in compulsory school pupils' L2 self-concepts: A longitudinal study. System, 37 (2), 177-193. 
Kim, Y.-K. \& Kim, T.-Y. (2011). Gender differences in Korean secondary school students' learning styles and L2 motivation. Foreign Languages Education, $18(2), 51-71$.

Kissau, S.P. (2006). Gender differences in motivation to learn French. Canadian Modern Language Review, 62 (3), 401-422.

Kissau, S.P., Kolano, L.Q, \& Wang, C. (2010). Perceptions of gender differences in high school students' motivation to learn Spanish. Foreign Language Annals, 43 (4), 703-721.

Kormos, J. \& Csizér, K. (2008). Age-related differences in the motivation of learning English as a foreign language: Attitudes, selves, and motivated learning behavior. Language Learning, 58 (2), 327-355.

Okuniewska, E., Okuniewska, H., \& Okuniewski, J.E. (2010). Motivation and attitudes of Polish students learning Hebrew. Psychology of Language and Communication, 14 (2), 71-79.

Öztürk, G. \& Gürbüz, N. (2013). The impact of gender on foreign language speaking anxiety and motivation. Procedia - Social and Behavioral Sciences, 70, 654-665.

Polat, N. (2011). Gender differences in motivation and L2 accent attainment: An investigation of young Kurdish learners of Turkish. Language Learning fournal, 39 (1), 19-41.

Williams, M., Burden, R., \& Lanvers, U. (2002). 'French is the Language of Love and Stuff': student perceptions of issues related to motivation in learning a foreign language. British Educational Research fournal, 28 (4), 503-528.

$\mathrm{Xu}, \mathrm{W}$. \& Case, R.E. (in press). Age-related differences in motivation in learning English among Mainland Chinese students. International fournal of Applied Linguistic. 